\title{
Consumer Buying Behavior at Shopping Malls: Does Gender Matter?
}

\author{
Ankit Katrodia, M.J. Naude, S. Soni \\ University of KwaZulu-Natal, Durban- Westville Campus- South Africa \\ University of KwaZulu-Natal, Pietermaritzburg - South Africa \\ KatrodiaA@ukzn.ac.za
}

\begin{abstract}
The development of shopping malls is a major social and global phenomenon that has unearthed a novel facet for customer satisfaction and their consequent or relative buying behavior. The aim of his paper was to explore the gender differences in consumer buying behavior at selected Durban shopping malls. It is an observational cross-sectional study carried out on 700 randomly selected respondents to study buying capacity, buying behavior and shopping experience of male and female consumers at shopping malls in the city of Durban, South Africa. Data was collected through pre-tested semi-structured questionnaire with closed ended questions. The study revealed that there are notable gender differences, which shape shopping behavior among men and women. Time and money spent at the mall was significantly high among female as compared to male consumers. Consequently, the results attributed that personal attributes and shopping mall attractiveness factors played a crucial role in influencing customer shopping behavior amongst the mall shoppers. The study concludes that gender differences are prevalent in the buying behavior of customers at the select shopping malls in Durban, South Africa. Average time spent by female is high as compared to male which also affect their average money spent at shopping mall. Psychological, Social and Cultural factors are highly influencing customers' buying behavior at shopping malls.
\end{abstract}

Keywords: Gender differences, Customer buying behavior, Shopping mall attractiveness, Ambiance, Personal attributes

\section{Introduction}

Over the last few decades, the retailing sector in South Africa has witnessed tremendous growth with the country's GNI (gross national income) per capita hitting US\$ 6,100 (Piotrowicz \& Cuthbertson, 2015).The entry of the country into the BRICS (Brazil, Russia, India, China, and South Africa) coupled with a population of over 50 million has provided a platform for the rise and flourishing of economic mercantile activities ranging from multinational corporations to shopping malls in its major cities (Ushakov, 2017). South Africa's retailing sector's context is characterised by the escalation in the number of shopping malls to meet the needs of the population segmented with high disposable income, high rates of urbanization, and trends of rapid economic growth patterns (Human Sciences Research Council., 2003). In the current business environment, shopping malls in the retail sector play a key role, as they expose consumers to a variety of products mostly under one roof (Gomez, Isakov, \& Semansky, 2015). According to Ozturk (2014), the business environment is continuously becoming more competitive, an aspect that is forcing shopping malls to adopt strategies to meet the diverse needs of their respective consumers. Despite the adoption of these strategies, many shopping malls have failed to understand the implication of consumers' buying behaviour, personal variables, and the overall gender differences on the shopping experience (Ismail \& Sohail, 2015). In this study, the focus is placed on seven shopping malls in Durban City. Durban City provides consumers with the exciting experience of shopping with diverse products ranging from domestic appliances, foodstuffs, and other variety of services (Turner, 2017). Given the diverse implications attributed to gender differences, it is inexcusable to disregard the significance of shopping malls in retail research. Therefore, the increase in the number of shopping malls has aggravated competition in respective contexts purposely to retain and attract new consumers (Ozturk, 2014).

Valentine and Powers (2013) identified the characteristics of the millennial generation that marks them as an important market segment that needs understanding from the marketers and mall managers. In addition to this, many studies place their focus on mature men and women who might be attracted to the mall based on their innovative design ideas, for example, furnished waiting areas, parking lots, and children's' playing areas (Giampino, Picone, \& Schilleci, 2017). Hami, Fazle, and Emami (2016) attribute the implication of sociodemographic factors on the case of interior landscape design in shopping malls as an influence to shopping behaviours manifested amongst female and male mall shoppers. Similarly, the studies of (Miremadi and 
Faghanie, 2012) revealed the influence of mall factors such as ambiance, services, and assortment amongst consumers' mall shopping behaviour. Existing research attributes the disparity between the shopping behaviour of men and women based on diverse factors. For example, Kushwaha, Rao, and Ahmad (2015) posit that the advancement in technology, diverse cultural and social factors are some of the factors harnessing and impacting the shopping behaviour of men and women. Within this context, researchers continue to pursue the causal links between gender differences, customer shopping behaviour, personal variables, and their respective capacities in shopping malls. This study, therefore, aims to explore the gender differences in shopping experience through an empirical investigation of the shopping malls in Durban City.

\section{Literature Review}

Shopping behaviour: In his study, Sohail (2015) explored the differences in the shopping behaviour of men and women in malls located across Saudi Arabia. The sample consisted of 513 shoppers who were recruited using a non-probability convenience sampling method. The results of the study revealed differences in shopping behaviour between gender and variables such as price and service quality (Sohail, 2015). In this case, it is imperative to note that consumers are exposed to diverse products and social amenities that not only define their shopping behaviour but also influence their shopping habits. Therefore, mall managers must ensure that their respective malls match the right pricing policies, significant lifestyle trends, socio-economic levels, to the shoppers' needs and attitude. Similarly, Kraljevic and Filipovic (2017) conducted a study amongst the millennial who are posing a challenge for shopping malls. Shopping malls are striving to strategies to match millennials shopping. Their study adopted an empirical analysis with the objectives of the study centred on the gender differences manifested in purchase behaviour, loyalty, pricing sensitivity, and unique shopping habits. Findings from the study revealed that women are more sensitive to pricing and preferred loyalty programmes when compared to the men. Similarly, Sohail (2015) accounts for the relationship manifested between women and shopping, for example, women having a high likelihood of shopping for a gift when compared to the men. Men living with their spouses tend to leave shopping such as household groceries to their spouses (Anne, Bisakha, Kilgore, and Locher, 2014). However, Emine and Fatma (2016) found that men's behaviour towards shopping has changed significantly. Trends that were earlier reserved for women, for example, buying clothes that involve careful comparison of prices and time taken to a make a purchase have now been adopted by men. The implication of such shopping trends augers well with the role of the socio-demographic factors and their influence on shopping behaviour noted through studies carried out by Bai, Yao, and Dou (2015), and Miremadi and Faghanie (2012).

Personal attributes: The ever-growing competition in the business environment has led marketers to research on strategies for identifying various personal attributes that influence consumer purchasing behaviour. According to Dobre and Milovan-Ciuta (2015) note that personality is often linked to instances where consumers are influenced to purchase and consume products. Shopping mall managers and marketers are aware of the personality linked characteristics and their role in forming patterns of life manifested through lifestyles, identify, and social relations amongst different customer segments. The relevance of communication with women is likely to require attention and mall attendants should be ready to offer them assistance on the assortment of items available at their disposal. Gohary and Hanzaee (2014) conducted a study to understand the influence of personality traits with shopping motivation amongst a group of college students. The study reported existing significant differences amongst males and females on openness, hedonic shopping behaviour, and neuroticism. Maximising on personal characteristics as manifested amongst men and women differently is an implication of the resulting shopping experience amongst the shoppers. Moreover, men are guided with one purpose; shop for the intended items and leave a store while women take time to scan the store as they maximize their shopping experience. Similarly, the findings of a study by Rehman, Yusoff, Zabri, and Ismail (2017) revealed the implication of personal factors as evidenced on shoppers' buying behaviour in the fashion industry. As an integral component in the shopping experience, malls have adopted marketing techniques that enable them to match the personal characteristics of shoppers - for example, interactions with sales attendants in a shopping mall elicits different reactions from men and women. Men view sales attendants to be there to help get their shopping done in a timely manner, while women prefer to get help on different products and in the case of fashion, trying on clothes. Given that shopping malls in Durban city offer a range of products and services, consumers are likely to be influenced differently and their shopping experience shaped differently. Furthermore, the evolving nature of the mall 
shopping experience characterised by new innovative ideas and technological advances plays a critical role in motivating and shaping individual shopping behaviour attributes (Prasad, 2012).

Shopping mall experiences: The increase of shopping malls in major cities is a significant improvement away from the traditional markets that did not offer such a range of diverse products in a sophisticated manner. Nevertheless, competition amongst shopping malls continues to impact consumers' behaviour and respective shopping experiences amongst male and female shoppers. Whereas women enjoy the shopping experience, men understand shopping differently as they take it as a task that needs to be completed (Sohail, 2015). Numerous studies have been conducted regarding the development of malls with attention drawn on their design, inside and outside ambiance and other pleasant stimuli, for example, the use of videos, refreshments, promotional activities, and their relevance in enhancing shopping experience amongst the shoppers (Mittal and Jhamb, 2016). Khare (2012) found that these strategies not only enhance positive buying decisions but also shape and influence different customer buying behaviour amongst male and female shoppers. Shukla and Babin (2013) investigated the impact of psychographic variables and store characteristics in motivating and influencing consumer shopping behaviour. Their study that the context of shopping stores' characteristics was manifested through assortment, after sales services, sales associates, and ambiance generates better consumer experience. The study also dealt with the differences of consumer buying behaviour between gender and their respective holistic assessments regarding the characteristics of the shopping malls.

The evaluation of shopping mall consumers indicates that most of consumers with strong shopping motives inevitably make decisions based on what appeals to them and this fostered by the mall environment that elicits and perpetuates their shopping behaviour and experience (Tandon, Gupta, and Tripathi,2016). For example, sales persons observe that men seldom ask where items they need are and where they cannot find them, whereas women will readily approach the sales person for help (Sigal Tifferet and Ram Herstein, 2012). Existing studies revealed the influence of shopping mall attractiveness in attracting consumers from different social classes (Mittal and Jhamb, 2016). Findings from a study conducted by ElAdly (2007) that explored attractiveness factors of shopping malls in the United Arab Emirates and their implication on shoppers' perspective revealed that comfort, diversity, convenience, luxury, and entertainment shaped their buying behaviour. Mittal and Jhamb (2016), and Makgopa (2016) echo similar thoughts in their studies with additional factors such as; mall location, parking spaces, and entertainment as traits shaping shopping experience and different customer buying behaviour amongst the men and women. Shopping malls that provide designated areas for children to play tend to attract more female consumers with those with parking lots also venturing into diverse customer segment. For example, men are likely to be appealed to a certain shopping mall because they have a parking, for the case of women, they simply love shopping. The everchanging consumers' habits and attitudes account for the embrace of these insights by shopping malls through a change in strategies.

\section{Methodology}

Present research is an observational cross-sectional study. All consumers of shopping malls in Durban city formed the study population for this research work.

Objectives: The objectives of this study were as follows:

- To study role of gender on consumers' buying behavior in select shopping malls in Durban

- To compare buying capacity of male and female consumers at selected shopping malls in Durban.

- To study gender differences in shopping experience at selected malls in Durban.

Null Hypotheses: To make study more scientific and to achieve the above objectives, the following proposed null hypothesis has been tested using appropriate statistical techniques.

- $\mathrm{H}_{01}$ : There is no role of gender on consumers' buying behavior in shopping malls.

- Hoz: Buying capacity of male and female consumers is not significantly different.

- $\mathrm{H}_{03}$ : There is no gender difference in shopping experience at shopping malls. 
Target population: All persons visiting malls for shopping at Durban city were the target population for this study.

Sample: The study was undertaken on 700 consumers of seven shopping malls in Durban city, Kwa-Zulu Natal, South Africa. From each selected mall100 consumers were randomly selected.

Data Collection Producer: From each selected shopping mall, one hundred customers were selected using Simple Random Sampling. Researcher had visited each mall personally and talked about the survey with the customers who were passing from him in the mall. Customers who had given oral concern to participate in the survey were selected for the study. In selection procedure, there was no restriction on ethnic groups, race, age, income and gender of the customers. The questionnaire was handed over to selected customer and got back filled questionnaire.

Data Collection Tool: The questionnaire consisted of closed-ended questions that included a 5-point Likert scale. To collect data from the source (customers of shopping malls), Pre-Tested, Close-Ended questionnaire was developed. Questions related to consumer buying behaviour, social factors, cultural factors, psychological factors and shopping experience at malls were included in the questionnaire.

Validity and Reliability: Internal reliability of the scores was checked using Cronbach's Alpha statistics. To validate the questionnaire, it was sent to four subject experts. Their opinion / suggestions was incorporated to finalise the tool. Thus, the questionnaire had "Content Validity" and "Reliability".

Data Analysis: Once the questionnaires were completed, it was coded, and data captured in Microsoft Excel. Once this was complete, the data was cleaned by cross verification before transferring it "STATA/MP version 13", statistical package for further analysis. Descriptive statistics were calculated to summarize nominal and categorical data using frequency and percentage whereas continuous data were summarized using mean, SD and CI. Mean scores of various factors were compared between male and female consumers using Independent t-test. Categorical and Normal data were compared using Pearson's Chi-Square test. Discriminant Function Analysis was carried out to predict gender from set of variables. Statistical significance was set at 5\% level. Ethical clearance was taken from institutional ethical committee.

\section{Results}

This section presents the findings and discussion of the findings. Continuous data are summarized in form of mean \pm SD throughout this discussion. Table 1 presents the demographic details of the respondents. It is clear from Table 1, that $53 \%$ of the respondents are female. The mean age of the respondents was 37.17 years. The majority of the respondent's (36.6\%) had a metric and $26.9 \%$ a diploma. Of the respondents, $45.3 \%$ were employed in the private sector and $32.6 \%$ in the public sector. With regard to respondents' income level, $21.9 \%$ had monthly income less than R 5000, 30\% earned between R 5000 to R 10000, 26.3\% earned between R 11000 to R 20000, 12.4 of the respondents earned between R21000 to R30000, whereas remaining $8.4 \%$ earned above R30000.It is clear from Table 2, that $12.3 \%$ of the respondents visited the mall daily whereas $51 \%$ visited it once a week. The proportion of male respondents who were visiting malls daily is high as compared to female respondents. There is no statistically significant association between frequency of visiting mall and gender of respondents (chi-square value $=8.641$, $\mathrm{p}$-value $=0.071$ ). 
Table 1: Profile of Respondents

\begin{tabular}{lll}
\hline Characteristics & Frequency(N=700) & Percentage (\%) \\
\hline Gender: & 336 & 48 \\
Females & 334 & 52 \\
Males & & \\
Age: & 144 & 20.6 \\
15 - 25 years & 202 & 28.9 \\
26-35 years & 150 & 21.4 \\
36- 45 years & 116 & 16.6 \\
46 - 55 years & 88 & 12.5 \\
Above 56 years & & \\
Educational Qualification & 55 & 7.9 \\
Below Matric & 256 & 36.6 \\
Matric & 188 & 26.9 \\
Diploma & 96 & 13.6 \\
Graduate & 105 & 15.0 \\
Post Graduate & & \\
Sector in which employed & 317 & 45.3 \\
Private sector & 228 & 32.6 \\
Public sector & 126 & 18.0 \\
Self employed & 29 & 4.1 \\
Other & & \\
Monthly Income & 153 & 21.9 \\
<R 5000 & 210 & 30.0 \\
R 5000 to R 10000 & 184 & 26.3 \\
R 11000 to R 20000 & 87 & 12.4 \\
R 21000 to R 30000 & 66 & 9.4 \\
\hline R 30000 & & \\
\hline
\end{tabular}

Table 2: Association of frequency of visit and at mall with Gender

\begin{tabular}{llllllll}
\hline Variables & & \multicolumn{2}{c}{ Male (n=336) } & \multicolumn{2}{c}{ Female (n=364) } & \multicolumn{2}{c}{ Total (n=700) } \\
\hline \multirow{5}{*}{ Frequency of visit mall } & Everyday & 47 & $14 \%$ & 39 & $10.7 \%$ & 86 & $12.3 \%$ \\
& Once in a week & 174 & $51.8 \%$ & 183 & $50.3 \%$ & 357 & $51 \%$ \\
& Once in a fortnight & 50 & $14.9 \%$ & 52 & $14.3 \%$ & 102 & $14.6 \%$ \\
& Once in a month & 40 & $11.9 \%$ & 70 & $19.2 \%$ & 110 & $15.7 \%$ \\
& Rarely & 25 & $7.4 \%$ & 20 & $5.5 \%$ & 45 & $6.4 \%$ \\
\hline
\end{tabular}

Gender Difference in factors affecting buying decisions: To know what the factors are affecting buying decisions of male and female consumers in shopping malls at Durban city, 22 different questions were asked to selected consumers for rating it in four-point Likert scale as 1: Highly influence to 4: Not at all influence. It should be noted that the lower the mean value, the greater the importance placed on the buying decision making factor. Table 3 provides mean scores given by male and female consumers for each question. To check gender difference in factors affecting buying decision, Independent t-test was used, and its p-value was obtained which is presented in the table. Using independent t-test the difference of mean score of each factor was compared between male and female respondents. Results show that mean scores of factors. "Mall Image and Popularity", "Evacuation Path" and "Information Booth" are significantly high among female as compared to male respondents ( $p$-value $<0.05$ ). It indicates that these factors are more important for females compared to males. On the remaining buying decision-making factors though, there were no significant differences between males and females meaning that both male and female customers place similar emphasis on such factors. 


\begin{tabular}{l} 
Journal of Economics and Behavioral Studies (ISSN: 2220-6140) \\
Vol. 10, No. 1, pp. 125-134, February 2018 \\
\hline \hline
\end{tabular}

Table 3: Gender difference in factors affecting buying decision in shopping malls

\begin{tabular}{llllll}
\hline Sr. No. & Factors & Male & Female & t-value & p-value \\
\hline 1 & Mall Image and popularity & $1.13 \pm 0.374$ & $1.26 \pm 0.595$ & -3.420 & $0.001^{*}$ \\
2 & Spacious shop floor & $1.16 \pm 0.371$ & $1.21 \pm 0.485$ & -1.542 & 0.124 \\
3 & Billing and checkout time & $1.26 \pm 0.445$ & $1.24 \pm 0.441$ & 0.512 & 0.609 \\
4 & Employee/Staff Behaviour and service & $1.49 \pm 0.512$ & $1.42 \pm 0.5$ & 1.926 & 0.055 \\
5 & Amenities & $1.5 \pm 0.513$ & $1.46 \pm 0.51$ & 1.214 & 0.225 \\
6 & Customer service quality & $1.49 \pm 0.535$ & $1.46 \pm 0.505$ & 0.530 & 0.596 \\
7 & Safety and Security & $1.38 \pm 0.556$ & $1.42 \pm 0.526$ & -0.823 & 0.411 \\
8 & Atmosphere & $1.37 \pm 0.559$ & $1.42 \pm 0.562$ & -1.075 & 0.283 \\
9 & Parking & $1.38 \pm 0.572$ & $1.4 \pm 0.559$ & -0.402 & 0.688 \\
10 & Play area for children & $1.46 \pm 0.64$ & $1.51 \pm 0.686$ & -0.938 & 0.349 \\
11 & Temperature control & $1.48 \pm 0.593$ & $1.43 \pm 0.578$ & 1.076 & 0.282 \\
12 & Attractive interior decor & $1.49 \pm 0.66$ & $1.48 \pm 0.614$ & 0.209 & 0.834 \\
13 & Elevators and escalators & $1.49 \pm 0.655$ & $1.52 \pm 0.632$ & -0.757 & 0.449 \\
14 & Marketing communications/Promotions & $1.49 \pm 0.665$ & $1.57 \pm 0.687$ & -1.571 & 0.117 \\
15 & Cleanliness & $1.44 \pm 0.616$ & $1.48 \pm 0.577$ & -0.828 & 0.408 \\
16 & Operating time & $1.45 \pm 0.621$ & $1.48 \pm 0.572$ & -0.690 & 0.490 \\
17 & Flexibility in payment mode & $1.47 \pm 0.622$ & $1.45 \pm 0.575$ & 0.622 & 0.534 \\
18 & Product return and exchange services & $1.48 \pm 0.66$ & $1.47 \pm 0.627$ & 0.254 & 0.799 \\
19 & Brand reputation of products & $1.52 \pm 0.673$ & $1.52 \pm 0.661$ & -0.136 & 0.892 \\
20 & Toilet/Washroom/ Baby room facility & $1.62 \pm 0.681$ & $1.64 \pm 0.757$ & -0.390 & 0.697 \\
21 & Information booth & $1.88 \pm 0.788$ & $2.06 \pm 0.801$ & -3.035 & $0.002^{*}$ \\
22 & Evacuation path & $2.21 \pm 0.839$ & $2.4 \pm 0.809$ & -3.090 & $0.002^{*}$ \\
\hline
\end{tabular}

* denotes significance at 5\% level.

Table 4: Ranks given to factors on the basis of their importance on buying decision

\begin{tabular}{lllll}
\hline Sr. No. & Factors & Rank by Males & Rank by Females & $\begin{array}{l}\text { Rank by } \\
\text { Sample }\end{array}$ \\
\hline 1 & Mall Image and popularity & 1 & 3 & 2 \\
2 & Spacious shop floor & 2 & 1 & 1 \\
3 & Billing and checkout time & 3 & 2 & 3 \\
4 & Employee/Staff Behaviour and service & 13 & 7 & 8 \\
5 & Amenities & 18 & 11 & 14 \\
6 & Customer service quality & 14 & 10 & 12 \\
7 & Safety and Security & 6 & 6 & 6 \\
8 & Atmosphere & 4 & 5 & 5 \\
9 & Parking & 5 & 4 & 4 \\
10 & Play area for children & 9 & 16 & 16 \\
11 & Temperature control & 11 & 8 & 7 \\
12 & Attractive interior decor & 15 & 15 & 15 \\
13 & Elevators and escalators & 16 & 17 & 19 \\
14 & Marketing communications/Promotions & 17 & 19 & 10 \\
15 & Cleanliness & 7 & 13 & 11 \\
16 & Operating time & 8 & 14 & 9 \\
17 & Flexibility in payment mode & 10 & 9 & 13 \\
18 & Product return and exchange services & 12 & 12 & 18 \\
19 & Brand reputation of products & 19 & 18 & \\
\hline
\end{tabular}




\begin{tabular}{lllll}
\hline 20 & Toilet/Washroom/ Baby room facility & 20 & 20 & 20 \\
21 & Information booth & 21 & 21 & 21 \\
22 & Evacuation path & 22 & 22 & 22 \\
\hline
\end{tabular}

Table 4 gives ranks allotted to factors on the basis of mean score given by respondents. As per the table, top five important factors for decision making are "Spacious Shop Floor", "Mall Image and Popularity", "Billing and Checkout Time", "Parking" and "Atmosphere" whereas bottom five (least important) factors are "Evacuation path", "Information Booth", "Toilet/Washroom/Baby room facility", "Marketing communication / Promotion" and "Brand Reputation of Products". There are few factors in which females were more concern than males, like... "Employee/Staff behaviour and service", "Amenities", "Customer Service Quality" whereas in factors like ... "Play Area for children", "Cleanliness" and "Operating time", males are more concern than females. It is further reported that mall attractiveness also plays a key role in influencing gender differences amongst the mall shoppers.

Cronbach's Alpha was obtained as a measure of internal consistency of scales related to factors influencing consumers' buying decision at shopping malls(Table-4). The value of Cronbach's Alpha was 0.752 which infers that the scale had high internal consistency. Above factors were grouped in three broad categories as follows. Factor number 1-4, 12,16-17 and 22 were grouped as "Psychological Factors" whereas number 5-8, $11,15,20-21$ were grouped as "Cultural Factors" and remaining factors were grouped as "Social Factors". Overall responses for all groups were obtained by calculating mode value of factors under them. After getting mode values, final data were converted in binary answer as "High Influence" and "Moderate/Low Influence". Further analysis was carried out to check association of gender with these three groups as follows.

Table 5: Association of gender with Psychological, Cultural and Social factors

\begin{tabular}{|c|c|c|c|c|c|c|}
\hline & & & Male $(n=336)$ & $\begin{array}{l}\text { Female } \\
(n=364)\end{array}$ & Total $(n=700)$ & $\begin{array}{l}\text { Chi-square } \\
\text { (p-value) }\end{array}$ \\
\hline \multirow{5}{*}{$\begin{array}{l}\text { Psychological } \\
\text { Factor }\end{array}$} & High & & $227(82.4 \%)$ & $295(81 \%)$ & $572(81.7 \%)$ & \multirow{5}{*}{$\begin{array}{l}0.228 \\
(0.633)\end{array}$} \\
\hline & Influence & & & & & \\
\hline & Moderate & / & $59(17.6 \%)$ & $69(19 \%)$ & 128(18.3\%) & \\
\hline & Low & & & & & \\
\hline & Influence & & & & & \\
\hline \multirow[t]{4}{*}{ Cultural Factor } & High & & $209(62.2 \%)$ & $222(61.6 \%)$ & 431(61.6\%) & \multirow{5}{*}{$\begin{array}{l}0.109 \\
(0.742)\end{array}$} \\
\hline & Influence & & & & & \\
\hline & Moderate & / & $127(37.8 \%)$ & $142(39 \%)$ & $269(38.4 \%)$ & \\
\hline & $\begin{array}{l}\text { Low } \\
\text { Influence }\end{array}$ & & & & & \\
\hline \multirow{5}{*}{ Social Factor } & Iniruence & & & & & \\
\hline & $\begin{array}{l}\text { High } \\
\text { Infly }\end{array}$ & & $237(70.5 \%)$ & $245(67.3 \%)$ & 482(68.9\%) & \multirow{4}{*}{$\begin{array}{l}0.849 \\
(0.357)\end{array}$} \\
\hline & Moderate & 1 & $99(29.5 \%)$ & $119(327 \%)$ & $218(31.1 \%)$ & \\
\hline & Low & & & & & \\
\hline & Influence & & & & & \\
\hline Overall & Good & & $221(65.8 \%)$ & $243(6.8 \%)$ & 464(66.3\%) & 0.076 \\
\hline Experience & $\begin{array}{l}\text { Neutral } \\
\text { Bad }\end{array}$ & / & $115(34.2 \%)$ & $121(33.2 \%)$ & $236(33.7 \%)$ & $(0.783)$ \\
\hline
\end{tabular}

To check association between gender and views on influence of Psychological, Cultural and social factors, Pearson's Chi-Square test was applied, and its p-value was obtained which are presented in Table 5. It infers that there is no significant association between gender and view regarding influence of Psychological, Cultural and Social factors on buying decision of selected respondents ( $p$-value $>0.05$ ). Among the three factor groups, respondents mean that compared to Cultural and Social, Psychological factors are more influencing on decision making. When they asked for their overall experience in shopping malls, male and female showed almost equal view (65.8\% male and $66.8 \%$ female said it was good). Thus, no significant difference was found in views regarding overall experience at mall between male and female respondents ( $p$ value $=0.783$ ). 
Table 6: Money and Time spent at shopping mall by male and female respondents

\begin{tabular}{llllll}
\hline & & Male (n=336) & $\begin{array}{l}\text { Female } \\
(\mathbf{n = 3 6 4 )}\end{array}$ & Total (n=700) & $\begin{array}{l}\text { Chi-Square } \\
\text { (p-value) }\end{array}$ \\
\hline \multirow{2}{*}{ Time spent } & $<2 \mathrm{hrs}$ & $198(58.9 \%)$ & $161(44.2 \%)$ & $359(51.3 \%)$ & 15.108 \\
\multirow{3}{*}{ Money spent } & $>2 \mathrm{hrs}$ & $138(41.1 \%)$ & $203(55.8 \%)$ & $341(48.7 \%)$ & $(<0.001)$ \\
& $<\mathrm{R} 200$ & $92(27.4 \%)$ & $63(17.3 \%)$ & $155(22.1 \%)$ & 10.284 \\
& $>$ R 200 & $244(72.6 \%)$ & $301(82.7 \%)$ & $545(77.9 \%)$ & $(0.001)$ \\
\hline
\end{tabular}

One of the aims of present study was to know buying capacity of male and female at shopping malls. To test difference in time \& money spent by male and female customers, Pearson's Chi-Square test was applied, and its p-value was obtained which are given in Table 6 . Female respondents spent significantly more money at malls then males $(82.7 \% \mathrm{v} / \mathrm{s} 72.6 \%)(\mathrm{P}$-value $=0.001)$. Time spent at mall is an important parameter to know the shopping behaviour of consumers. In present study 138 (41.1\%) male and 203 (55.8\%) female respondents had spent more than two hours at mall. It concludes that females spent significantly more time at shopping malls compared to males (p-value <0.001) (Table 5). Gohary and Hanzaee (2014) and Rehman et al. (2017) attributed factors that differentiate men's shopping habits to those manifested by women. There were $14.3 \%$ male and $4.4 \%$ female respondents who spent less than one hour in a mall whereas $22.5 \%$ female and $17.6 \%$ male respondents spent more than four hours. Time spent at mall by respondents and their gender are significantly associated (Chi-Square value $=27.581$, $\mathrm{p}$-value $<0.001$ ).

\section{Conclusion}

This study evidences the existence of significant gender differences of customer shopping behavior amongst the mall shoppers. Understanding the aspect of the gender differences from the shopping experience of mall shoppers provides mall managers with rich information of approaching different customer segment with appropriate strategies. The findings of this study provide an insight in understanding the impact of gender difference in shopping mall experience. Thus, the study concludes that there is gender difference in shopping behavior in Durban city. Average time spent by female is high as compared to male which also affect their average money spent at shopping mall. Psychological, Social and Cultural factors are highly influencing customers' buying behavior at shopping malls. Male and female customers have almost similar views on influencing factors for shopping behavior except for few factors like mall image, information booth and evacuation path.

Suggestions: On the basis of above results, following suggestions has been given to managers / managements of shopping malls.

- Mall managers should pay more attention on customer's service counters to satisfy customers' quarries.

- Mall location and image is more important for customers for shopping experience. Hence management should give more emphasis on factors which improves image of the mall like quality of service, brand of items, tagging the items, parking facility and entertainment area.

- As time spent by female customers is high as compared to male, special attention on things which attract and give more options in shopping items like brand, style, new fashion, competitive rates, etc. It results in spending more time at mall which indirectly convert in high rate of shopping.

- There are good number of customers who are happy with shopping with experiencing good food and entertainment. They come to mall in week end to spare time with family. Looking at this scenario, managers should provide children pay area, food carts and cinema in mall so that majority of the requirement will satisfy. It can be results as increase in income of the mall.

- There may be additional factors that could contribute towards shopping experience. For instance, some shops or shopping centers provide additional entertainment during festive seasons (such as Diwali, Christmas, Thanks giving, and Easter and during Public holidays).

- To get more in-depth knowledge regarding factors which influence consumers' behavior towards shopping at malls, a qualitative research, in form of focused group discussion or personal interview, should be proposed. 


\section{References}

Anne, F. L., Bisakha, S., Kilgore, M. L. \& Locher, J. L. (2014). The Influence of Gender, Age, Education, and Household Size on Meal Preparation and Food Shopping Responsibilities. Public Health Nutrition, 17(9), 2061-2070.

Anushree Tandon, Ashish Gupta, Vibhuti Tripathi. (2016). Managing shopping experience through mall attractiveness dimensions: An experience of Indian metro cities. Asia Pacific Journal of Marketing and Logistics, 28(4), 634-649, https://doi.org/10.1108/APJML-08-2015-0127

Bai, Y., Yao, Z. \& Dou, Y. (2015). Effect of social commerce factors on user purchase behavior: An empirical investigation from renren.com. International Journal of Information Management, 35(5), 538-550. doi: 10.1016/j.ijinfomgt.2015.04.011

Dobre, C. \& Milovan-Ciuta, A. M. (2015). Personality influences on online stores consumer's behavior. Ecoforum, 41(6), 70-76.

El-Adly, M. I. (2007). Shopping malls attractiveness: a segmentation approach. International Journal of Retail \& Distribution Management, 35(11), 936-950, https://doi.org/10.1108/09590550710828245

Emine, K. \& Fatma, K. (2016). A Study of Clothing Purchasing Behavior by Gender with Respect to Fashion and Brand Awareness. European Scientific Journal, 12(7).

Giampino, A., Picone, M. \& Schilleci, F. (2017). The shopping mall as an emergent public space in Palermo. The Journal of Public Space, 2(2), 85-98.

Gohary, A. \& Hanzaee, K. H. (2014). Personality Traits as Predictors of Shopping Motivations and Behaviours: A Canonical Correlation Analysis. Arab Economic and Business Journal, 9(2), 166-174.

Gomez, R., Isakov, A. \& Semansky, M. (2015). Small business and the city: Transformative potential of smallscale entrepreneurship, University of Toronto Press, Toronto.

Hami, A., Fazle, F. \& Emami, F. (2016). Factors Affecting People Preferences toward Environment Landscape, Case Study: Shopping Mall in Kuala Lumpur. International Journal of Construction Engineering and Management, 5(4), 108-117.

Khare, A. (2012). Influence of mall attributes and demographics on Indian consumers' mall involvement behavior: An exploratory study. Journal of Targeting, Measurement and Analysis for Marketing, 20(34), 192-202.

Kraljević, R. \& Filipović, Z. (2017). Gender Differences and Consumer Behavior of Millennials, Acta Economica Et Turistica, 3(1), 5-13.

Kushwaha, B. P., Rao, N. S. \& Ahmad, S. Y. (2015). The factors influencing consumer buying decision of electronic products, Management Dynamics, 15(1), 5-15.

Makgopa, S. (2016). Determining consumers' reasons for visiting shopping malls. Innovative Marketing (hybrid), 12(2), 21-27.

Miremadi, A. \& Faghanie, E. (2012). An empirical study of consumer buying behavior and its influence on consumer preference in Iranian FMCG market: a case study. International Business and Management, $5(1), 146-152$.

Mittal, A. \& Jhamb, J. (2016). Determinants of Shopping Mall Attractiveness: The Indian Context. Procedia Economics and Finance, 37, 386-390.

Moreillon, O., Muller, A., Stiebel, L. \& Frey, S. T. (2017). Cities in Flux: Metropolitan spaces in South African literary and visual texts: Festschrift in honor of Professor Em. Dr. Therese Steffen. Münster Lit Verlag, Zurich.

Ozturk, G. (2014). Handbook of research on the impact of culture and society on the entertainment industry, Information Science Reference, Hershey, PA.

Piotrowicz, W. \& Cuthbertson, R. (2015). Supply chain design and management for emerging markets: Learning from countries and regions, Cham: Springer, 2015.

Prasad, Y. R. (2012). A study on attributes influencing the purchasing behavior of apparel consumers in organized outlets. African Journal of Business Management, 6(45), 11294-11303.

Rehman, F., Yusoff, R. B. M., Zabri, S. B. M. \& Ismail, F. B. (2017). Determinants of personal factors in influencing the buying behavior of consumers in sales promotion: a case of fashion industry. Young Consumers, 18(4), 408-424, https://doi.org/10.1108/YC-06-2017-00705

Shukla, P. \& Babin, B. J. (2013). Effects of consumer psychographics and store characteristics in influencing shopping value and store switching. Journal of Consumer Behavior, 12(3), 194-203. doi:10.1002/cb.1411 
Sigal, T. \& Herstein, R. (2012). Gender differences in brand commitment, impulse buying, and hedonic consumption. Journal of Product \& Brand Management, 21(3), 176182, https://doi.org/10.1108/10610421211228793

Sohail, M. S. (2015). Gender differences in mall shopping: a study of shopping behavior of an emerging nation. Journal of Marketing and Consumer Behavior in Emerging Markets, 1(1), 36-46.

Thomas, T. \& Carraher, C. E. (2014). A retail perspective on the shopping behavior, cultures and personalities for China, United Arab Emirates, Belgium, India, Germany and America. Journal of Technology Management in China, 9(3), 289-296

Turner, P. (2017). A psychology of user experience: Involvement, affect and aesthetics, Springer, Cham, Switzerland.

Ushakov, D. S. (2017). Economic reforms for global competitiveness, Business Science Reference, Hershey.

Valentine, D. B. \& Powers, T. L. (2013). Generation Y values and lifestyle segments. Journal of Consumer Marketing, 30(7), 597-606, https://doi.org/10.1108/JCM-07-2013-0650. 